Jurnal

Kardiologi Indonesia

J Kardiol Indones. 2014;35:96-10 I

ISSN 0I 26/3773

\title{
Diagnosis Sindrom Brugada
}

\author{
Edward Faisal
}

Department of Cardiology And Vascular Medicine Faculty Of Medicine, Universitas Indonesia Jakarta
Brugada syndrome is an inherited autosomal dominant disease that cause sudden death, which related with mutation of SCN5A gene, $\alpha$ subunit of sodium channel. The risk Brugada syndrome in male is 8 times more than females. The average age is 40 years old, which can happen between age I to 77 years old. The Incidence is 5 to 66 per 10.000 people. The golden diagnostic tools is ECG, an abnormality QRS-T found in lead VI-V3. I report a case of Brugada syndrome with neither sign nor symptoms. The disease coincidental in routine medical examination.

(J Kardiol Indones. 20 I4;35:96-I0 I)

Keywords: Brugada syndrome, sudden death, ECG, no sign and symptoms. 


\title{
Diagnosis Sindrom Brugada
}

\author{
Edward Faisal
}

\begin{abstract}
Sindrom Brugada adalah penyakit penyebab kematian mendadak yang diturunkan secara autosomal dominan, berhubungan dengan mutasi gen SCN5A, subunit $\alpha$ dari sodium channel. Resiko laki-laki menderita sindrom Brugada adalah 8 kali lebih besar dari perempuan. Usia rerata adalah 40 tahun, dengan rentang usia antara 1-77 tahun. Insidennya adlaah 5-66 per 10.000 orang. Alat diagnosis utama adalah EKG, dimana ditemukan abnormalitas QRS-T pada lead V1-V3. Saya akan melaporkan kasus sindrom Brugada tanpa adanya keluhan dan gejala. Sindrom ini ditemukan kebetulan pada pemeriksaan rutin.
\end{abstract}

(J Kardiol Indones. 2014;35:96-101)

Kata kunci: Sindrom Brugada, kematian mendadak, EKG, tanpa keluhan dan gejala.

S indrom Brugada adalah suatu aritmia jantung yang tidak berhubungan dengan adanya kelainan sruktural yang diturunkan secara autosomal dominan. Sindrom Brugada adalah penyebab kematian mendadak. Diagnosis lebih awal adalah suatu hal terbaik untuk dapat mencegah kematian. Sindrom Brugada ini tidak menyebabkan manifestasi yang khas, sehingga dianggap suatu hal umum oleh penderitanya. Karena itu perlu ketelitian untuk dapat mendiagnosis sindrom Brugada ini, yang hanya dapat dilakukan dengan pemeriksaan EKG.

\section{Ilustrasi Kasus}

Pasien laki-laki, usia 52 tahun, warga negara Indonesia datang ke Balai Kesehatan Penerbangan untuk melaksanakan evaluasi rutin sebagai penerbang pada

\section{Alamat Korespondensi}

dr. Edward Faisal. Yayasan Kesehatan Garuda Indonesia.

E-mail: dr.edwardfaisal@gmail.com. tanggal 3 Maret 2014, tanpa adanya keluhan sakit. Pada pemeriksaan fisik tidak ditemukan kelainan. Setelah dilakukan EKG, ditemukan kelainan pada lead precordial lead (V1, V2, V3) berupa ST Elevasi (Gambar 1). Berdasarkan gambaran EKG ini maka pasien didiagnosa sindrom Brugada. Kemudian dikonsulkan ke poli Jantung.

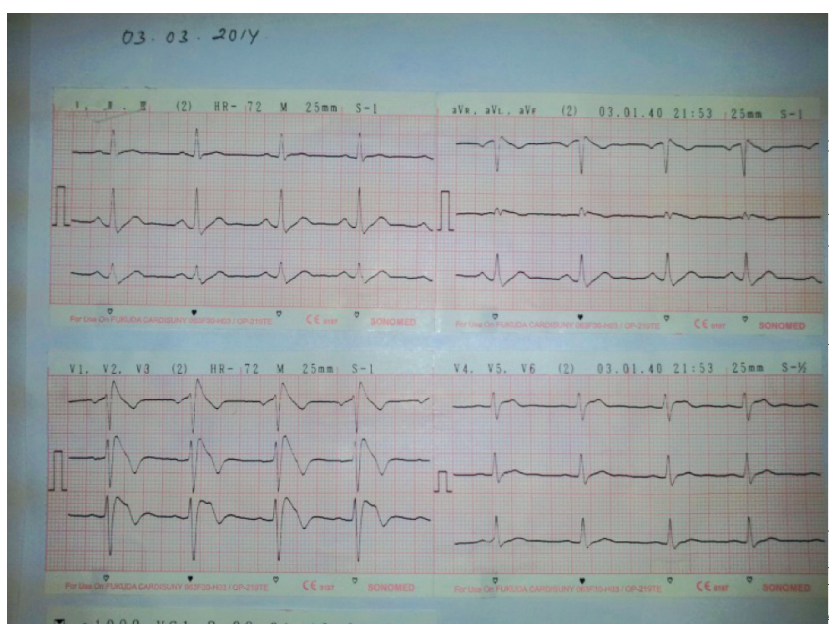

Gambar 1. EKG 03.03.2013 
Pada tanggal 5 Maret 2014 pasien kemudian datang ke Poli Jantung untuk tindak lanjut. Dari anamnesa diperoleh data pasien tidak ada keluhan, tidak menderita tekanan darah tinggi, tidak menderita diabetes, tidak merokok, tidak pernah sinkop, dan

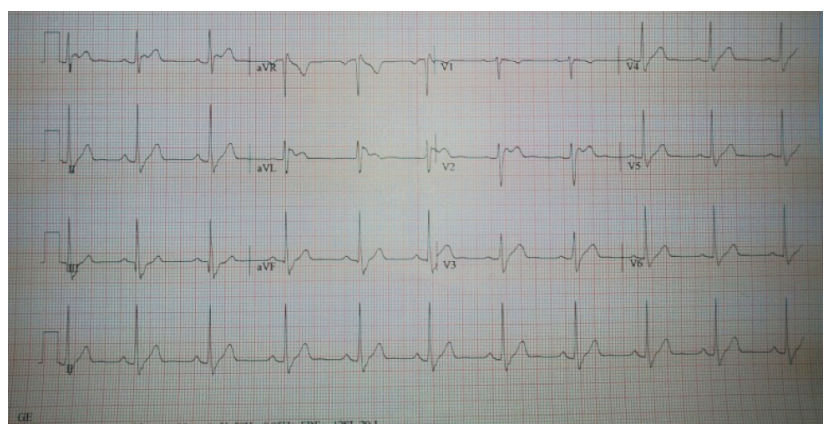

Gambar 2. EKG 05.03.2013

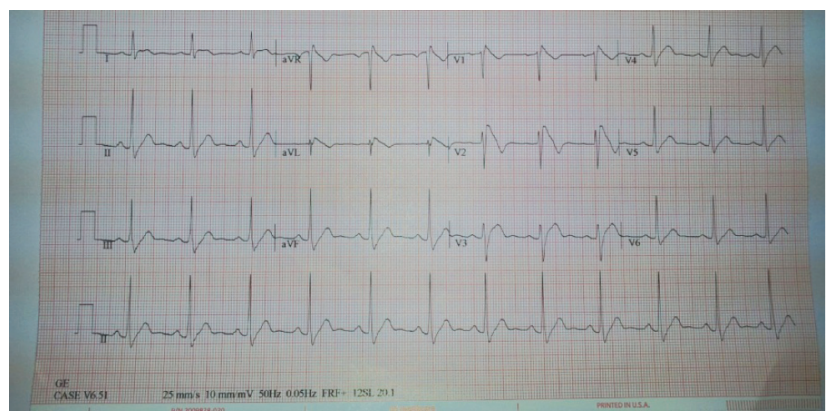

Gambar 3. EKG 19.03.2013 dalam keluarga tidak ada yang pernah sinkop maupun meninggal pada usia muda. Pemeriksaan fisik tidak ditemukan kelainan, kemudian dilakukan pemeriksaan EKG (Gambar 2). Hasil interpreatsinya adalah RBBB dengan diagnosis banding sindrom Brugada tipe 2 . Kemudian pasien diminta kembali kontrol untuk melakukan pemeriksaan ulang pada tanggal 19 Maret 2014.

Pada tanggal 19 Maret 2014 diperoleh gambaran lebih jelas dari pemeriksaan EKG yang mengarahkan ke diagnosis sindrom Brugada. Ini ditentukan berdasarkan adanya gambaran ST elevasi pada lead V1, V2, V3 dan tidak ditemukan gambaran yang sama pada lead lainnya. Untuk menguatkan diagnosis dan second opinion, maka pasien dirujuk ke Rumah Sakit Jantung Harapan Kita untuk dilakukan pemeriksaan eletrofisiologi lebih mendalam. Alasan ini dilakukan karena profesi pasien ini adalah seorang pilot, jika positif pasti terdiagnosis sindrom Brugada maka pasien ini tidak mendapat izin untuk menjalankan profesinya. Dikhawatirkan jika terjadi serangan saat menerbangkan pesawat dapat mengancam kru lainnya dan para penumpang.

Pemeriksaan elektrofisiologi yang dilakukan pada 27 Maret 2014 di RS Jantung Harapan Kita dinyatakan bahwa pasien menderita sindrom Brugada tipe 1. Ini dipastikan dengan memindahkan lead prekordial lebih superior 1 sela iga, tampak ST elevasi yang jelas pada lead V1,V2, V3.

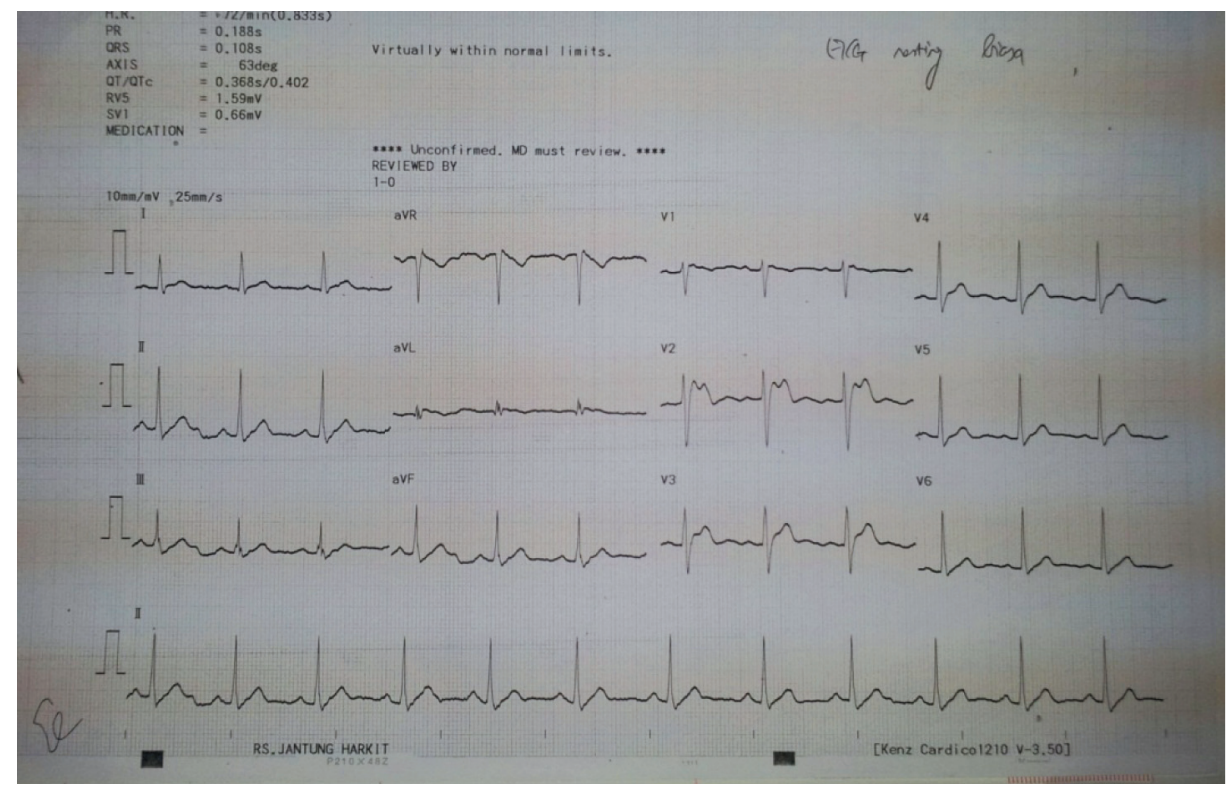

Gambar 4. EKG 27.03.2014 


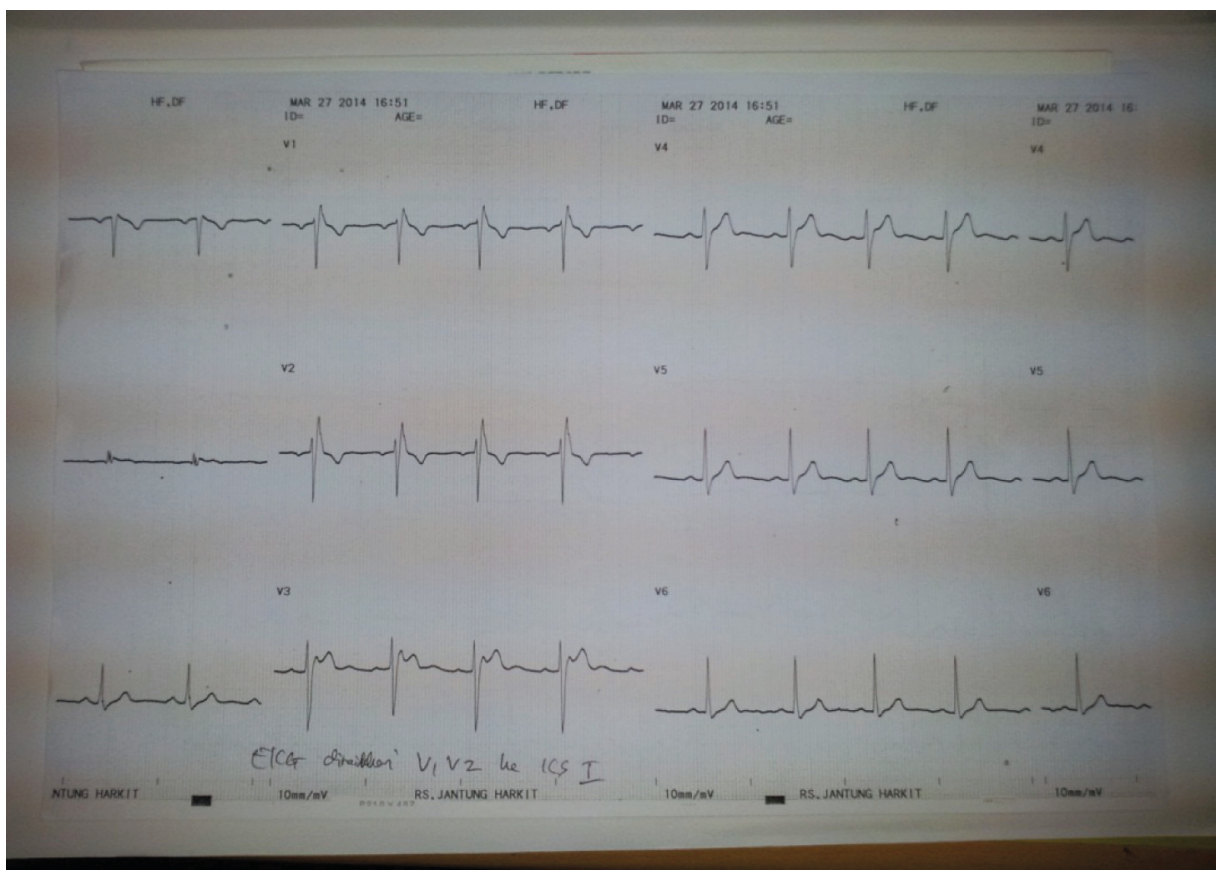

Gambar 5. EKG 27.03.2014 (lead prekordial dipasang lebih superior 1 sela iga)

\section{Tinjauan Pustaka dan Diskusi}

Orang yang berusia muda dengan keadaan anatomi jantung yang normal dapat juga dapat meninggal secara mendadak. ${ }^{1} \mathrm{Hal}$ ini berhubungan dengan terjadinya aritmia jantung. Ada aritmia jantung yang berhubungan dengan anatomi jantung yang normal maupun abnormal.

Banyak aritmia jantung yang diturunkan secara genetik, sebagian besar disebabkan oleh gangguan ion channel. ${ }^{2,3}$ Salah satu diantaranya yang sering mengakibatkan kematian mendadak adalah sindrom Brugada. $^{3}$

Sindrom Brugada adalah penyakit jantung yang diturunkan secara genetik ${ }^{1,4,5}$, bersifat autosomal dominan. ${ }^{4,5}$ Pada sindrom ini tidak ditemukan kelainan struktural, hal ini bisa dibuktikan dengan melakukan autopsi post mortem. ${ }^{6}$ Sindrom Brugada tidak berhubungan dengan iskemia, gangguan elektrolit, atau kelainan struktural jantung, akan tetapi berhubungan dengan resiko terjadinya kematian mendadak. ${ }^{4}$

Sindrom Brugada ini berhubungan dengan mutasi pada gen SCN5 $\mathrm{A}^{3,5,7}$, gen yang mengkode untuk subunit $\alpha$ dari sodium channel. ${ }^{4,7}$

Adanya mutasi genetik SCN5A ditemukan pada tahun 1998, sejak itu lebih dari 100 kasus baru ditemukan. Mutasi yang sudah terjadi adalah missense mutation, nonsense mutation, nucleotide insertion/ deletion, dan splice site mutation. ${ }^{5}$

Gangguan fungsi terjadi karena penurunan ekspresi protein 1,5 $\mathrm{Na}$ di sarkolema, ekskresi saluran nonfungsional, atau adanya perubahan di gerbang saluran $\mathrm{Na}$ (penundaan aktivasi, inaktivasi lebih awal, inaktivasi lebih cepat, peningkatan inaktivasi lambat, dan penurunan pemulihan dari inaktivasi). ${ }^{5}$

Mekanisme patofisiologi elevasi segmen ST dan takiaritmia ventrikuler merupakan keadaan yang berhubungan erat dengan sindrom Brugada, akan tetapi masih kontroversi. ${ }^{8}$

Lebih dari dua dekade ini, sejak sindrom Brugada dilaporkan sebagai sindrom kematian mendadak menunjukkan adanya gambaran RBBB dan elevasi segmen ST. ${ }^{9}$

Endemi sindrom Brugada adalah di negara asia tenggara dan asia timur ${ }^{2,8}$, prevalensi yang tertinggi di negara Jepang ${ }^{8}$ dan Tailand ${ }^{2,8}$, sedangkan yang memiliki insiden rendah adalah negara Cina dan Korea. ${ }^{2}$ Di Filipina dan Jepang prevalensi mencapai 0,5-1 per 1000 orang. ${ }^{2}$ Di Eropa, secara luas juga ditemukan sindrom Brugada, kecuali di negara-negara Scadinavia. ${ }^{8}$ 
Insiden sindrom Brugada adalah antara 5 sampai 66 per 10.000 orang. Negara-negara di asia tenggara merupakan daerah endemik sindrom Brugada. ${ }^{4}$

Rasio antara laki-laki dan perempuan adalah 8:1.2,4 Usia rata-rata terjadinya aritmia pada penderita sindrom Brugada adalah sekitar 40 tahun, dimana rentang usia terjadinya aritmia antara usia 1-77 tahun. ${ }^{4}$

Usia rerata terjadinya gejala pertama kali, baik laki-laki dan perempuan terjadi pada dekade ketiga dan keempat. Insidennya lebih banyak ditemukan pada pasien dengan riwayat keluarga yang memiliki anak dengan menunjukkan gejala sindrom Brugada. Ditemukan juga pasien sindrom Brugada dengan manifestasi klinis pertama kali terjadi pada usia 77 tahun. ${ }^{6}$

\section{Manifestasi Klinis}

Sinkope atau kematian mendadak adalah gejala utama sindrom Brugada. Pada monitoring pasien ini dapat ditemukan VT polimorfik, yang merupakan penyebab utama terjadinya manifestasi klinis. Delapan puluh persen pasien dengan riwayat $\mathrm{VF}$, akan ditemukan juga riwayat pernah mengalami sinkope. ${ }^{6}$

Sindrom Brugada umumnya terjadi pada saat pasien sedang tidur, terutama menjelang pagi hari. ${ }^{6}$

Kondisi yang dapat memberikan gambaran pola seperti sindrom Brugada adalah RBBB, atlit, pectus excavatum, dan ARVD. ${ }^{6}$

\section{Diagnosis}

Jika pada pemeriksaan EKG ditemukan gambaran pola sindrom Brugada, maka perlu dievaluasi lebih lanjut tentang: ${ }^{6}$

- Riwayat selamat dari kematian mendadak;

- Riwayat gambaran VT polimorfik;

- Riwayat sinkop nonvagal;

- Riwayat keluarga ada yang meninggal pada usia < 45 tahun tanpa adanya sindrom koroner akut;

- Riwayat adanya gambaran EKG pola ST segmen relatif.

Perubahan EKG pada penderita sindrom Brugada dapat dilihat di lead prekordial, yaitu morfologi QRS-T di lead V1-V3: ST elevasi (kadang hanya di lead V1 dan sering tidak ditemukan di V3).

Sindrom Brugada yang awalnya dibagi menjadi tiga tipe pola, berdasarkan konsensus terakhir pada tahun 2012, pembagiannya menjadi dua, yaitu tipe $1 /$ coved pattern dan tipe $2 /$ saddle-back pattern. ${ }^{6}$

Sindrom Brugada tipe 1, gambaran EKG yang ditemukan adalah elevasi segmen ST pada awal segmen sebesar $\geq 2 \mathrm{~mm}$, kemudian perlahan-lahan menurun dan menjadi konkaf atau persegi (yang berhadapan langsung dengan garis isoelektrik), dengan gelombang T yang simetris. ${ }^{6}$

Sindrom Brugada tipe 2 , gelombang $\mathrm{r}^{1}$ mengalami peningkatan $\geq 2 \mathrm{~mm}$ lebih tinggi dari garis isoelektrik dan diikuti dengan elevasi segmen ST; bentuk gelombangnya konveks dengan elevasi $\geq 0,05 \mathrm{mV}$ diikuti oleh gelombang $\mathrm{T}$ yang positif atau datar di lead V2, dan bentuk gelombang T di V1 bervariasi. Jika ada keraguan $\left(\mathrm{r}^{1}\right)$, maka perlu mengulang perekaman EKG pada ICS (inter costa space) 2 dan $3 .^{6}$

Yang perlu diperhatikan adalah sering adanya RBBB yang menutupi elevasi segmen ST pada gambaran EKG pasien sindrom Brugada. ${ }^{9}$

Teknik pemeriksaan EKG lainnya, pada keadaan tertentu, dapat dilakukan pada saat setelah olah raga. Latihan dilakukan untuk menemukan petunjuk baru, yang berpotensi, dan gangguan dinamika gelombang QT pada pemeriksaan dengan menggunakan holter. Pemeriksaan elektrofisiologi ini masih kontroversi untuk diagnosis dan stratifikasi resiko. ${ }^{6}$

Pola sindrom Brugada dapat ditemukan pada pasien dengan kecurigaan menderita sindrom Brugada. Caranya dengan memberikan sodium channel blokers yaitu flecanide, ajmaline, dan procainamid. ${ }^{4}$ Kontraksi jantung yang melambat akan lebih menunjukkan gambaran sindrom Brugada.

Gambaran EKG yang dapat ditemukan setelah pemberian ajmaline adalah ditemukan gelombang $\mathrm{r}^{1}$ di aVR $>3 \mathrm{~mm}$, yang menandakan adanya repolarisasi awal di lead inferior, fractioned QRS, dan gelombang T alternans. ${ }^{6}$

\section{Diagnosis Banding}

Abnormalitas yang dapat mengakibatkan elevasi segmen ST pada lead prekordial: ${ }^{4}$

- RBBB/LBBB, hipertrofi ventrikel kanan

- Iskemia/infark miokard akut

- Miokarditis akut

- Iskemia/infark miokard ventrikel kanan

- Diseksi aneurisma aorta

- Tromboemboli pulmonal akut 
- Berbagai macam abnormalitas sistem syaraf pusat dan otonom

- Overdosis antidepresan heterosiklik

- Distrofi muskular Duchene

- Ataxia Friederich

- Defisiensi tiamin

- Hipercalsemia

- Hiperkalemia

- Intoksikasi kokain

- Tumor mediastinum yang mengkompresi jalur aliran ventrikel kanan ( $R V O T)$

- Arrhythmogenic right ventricular dysplasia (ARVD)l cardiomyopathy

- Long QT syndrome, tipe 3

- Kondisi lainnya: sindrom repolarisasi awal, variasi normal lainnya yang umumnya terjadi pada lakilaki.

\section{Ringkasan}

Telah dilaporkan kasus seorang pasien laki-laki, berusia 52 tahun dengan diagnosa awal adalah sindrom Brugada oleh pemeriksa kesehatan saat pemeriksaan rutin. Ini berdasarkan dari hasil intepretasi EKG, adanya kelainan di lead V1, V2, V3 berupa ST Elevasi.

Kemudian pasien dirujuk ke spesialis Jantung untuk memastikan diagnosisnya. Didapatkan diagnosis $\mathrm{RBBB}$, diagnosis bandingnya adalah sindrom Brugada tipe 2. Karena penentuan diagnosis sindrom Brugada sangat penting, maka Kardiolog melakukan pemeriksaan ulang 2 minggu kemudian, dan diperoleh gambaran EKG yang lebih jelas mengarahkan ke diagnosis sindrom Brugada.

Kemudian untuk diagnosis akhir, pasien dirujuk melaksanakan pemeriksaan elektrofisiologi. Berdasarkan EKG ,dignosisnya menjadi pasti setelah lead prekordial dinaikan 1 sela iga dan dibandingkan dengan EKG pada posisi normal. Hasilnya adalah pasien menderita sindrom Brugada tipe 1.

\section{Daftar Pustaka}

1. Schwartz PJ. Introduction of Arrythmogenic Disorders of Genetic Origin Series. Circ Arrhythm Electrophysiol. 2012; 5 : 604-605.

2. Priori SG, Wilde AA, Horie M, Cho Y, Behr ER, Berul C, et al. Executive Summary: HRS/EHRA/APRHRS expert consensus statement on the diagnosis and management of patients with inherited primary arrthmia syndrome. Europace. 2013; 15: 1389-1406.

3. Anzelevitch et al. Issue Highlights. Function Mutations in The Cardiac Calcium Channel Underline A New Clinical Entity Characterized by ST-Segment Elevation, Short QT Intervals, and Sudden Cardiac Death. Circulation. 2007; 115: 13f-16f.

4. Wilde AM, Anzelevitch C, Boggrefe M, Brugada J, Brugada R, Brugada P, et al. Proposed Diagnostic Criteria for the Brugada Syndrome: Consensus Report. Circulation. 2012; 106: 25142519.

5. Mizusawa Y, Wilde AAM. Brugada Syndrome. Circ Arrhythm Electrophysiol. 2012; 5: 606-616.

6. Luna ABD, Brugada J, Baranchuk A, Bogreffe M, Breithardt G, Goldwasser D, et al. Current Electrocardiographic Criteria for diagnosis of Brugada pattern: a consensus report. Journal of Electrocardiology. 2012; 45: 433-442.

7. Chen PS, Priori SG. The Brugada Syndrome. JACC. 2008; 51 : 1176-80.

8. Meregalli PG, Wilde AAM, Tan HL. Review Pathophysiological Mechanism of Brugada Syndrome: Depolarization disorder, repolarization disorder, or more? Cardiovascular Research. 2005; 67: 367-378.

9. Aizawa Yoshiyasu, Kimura Takehiro, and Seiji Takatsuki. EP Case Report: A Case of Brugada Syndrome Showing Augmentation of Electrocardiogram Phenotype by Complete Bundle Branch Block. Europace. 2013; doi: 10.1093/europace/eut 219. 